\title{
Fatal poisoning with plant growth regulator - chlormequat
}

\author{
V Vijitharan ${ }^{1}$, J Warnasekare ${ }^{2}$, N C Lokunarangoda ${ }^{3}$ M F Farah ${ }^{1}$, S H Siribaddana ${ }^{3}$
}

Ceylon Medical Journal 2016; 61: 89-90

DOI: http://doi.org/10.4038/cmj.v61i2.8297

\section{Introduction}

Globally, $30 \%$ of suicidal deaths are caused by selfpoisoning with pesticides [1]. Deaths due to suicidal or intentional ingestion of plant growth regulators are rare. We report a case of suicide after consuming chlormequat chloride [(2-chloroethyl) tri-methyl-ammonium chloride; $\left.\mathrm{C}_{5} \mathrm{H}_{13} \mathrm{Cl}_{2} \mathrm{~N}\right]$ a quaternary ammonium compound and a plant growth regulator. It is used widely in agriculture to reduce unwanted longitudinal shoot growth without lowering plant productivity [2]. Chlormequat $\left(\right.$ Cycocel $\left.^{\circledR}\right)$ is not approved for plants consumed by humans and animals in USA, but is approved in Europe [2, 3]. In Sri Lanka it is used during cultivation of vegetables, fruits and floriculture. There are four case reports and a case series of seven patients with acute poisoning reported previously [4-9]. Ten out of these eleven cases have been fatal. One was after inhalation and the others were after ingestion of chlormequat chloride. Clinical features of acute poisoning are cholinergic crisis, cardiac arrest, acute pulmonary oedema, respiratory failure and death mostly within an hour of ingestion. Atropine has been used in four cases. Death occurred within a day of exposure in all fatal cases [4-9].

\section{Case report}

A 50-year old male farmer was admitted to the emergency treatment unit of Teaching Hospital, Anuradhapura following ingestion of $200 \mathrm{ml}$ of ' $\mathrm{Cycocel}{ }^{\circledR}$, under the influence of alcohol. Thirty minutes later he developed abdominal pain, vomiting and dyspnoea. On the way to hospital he became unconscious.

On admission the Glasgow coma scale was three, pupils were small (less than $2 \mathrm{~mm}$ ) and reactive to light, heart rate was 21 beats per minute, blood pressure was not recordable, respiratory rate was eight per minute and peripheral arterial oxygen saturation was undetectable by pulse oximetry. Atropine was given and cardiopulmonary resuscitation initiated. Heart rate increased to 130 beats per minute and blood pressure increased to $120 / 90 \mathrm{~mm} \mathrm{Hg}$. He had bilateral crackles heard over the chest and oxygen saturation was $95 \%$ with $\mathrm{FiO}_{2}$ of $100 \%$. After endotracheal intubation, gastric lavage was performed. Activated charcoal and intravenous cefuroxime were administered.

The chest X-ray showed pulmonary congestion with right lower zone opacities. There was neutrophil leukocytosis and sinus bradycardia. He had metabolic acidosis. The $\mathrm{pH}$ was 7.28 (normal range 7.35-7.45), $\mathrm{HCO}_{3}$ was $18 \mathrm{mmol} / \mathrm{l}$ (normal range 22-26) with hypoxia and $\mathrm{PaO}_{2}$ was $60 \mathrm{mmHg}$ (normal range 75-100). Serum creatinine was $126 \mu \mathrm{mol} / \mathrm{l}$ (normal range 70-120), and serum potassium was $3.2 \mathrm{mmol} / \mathrm{l}$ (normal range 3.5-4.5). Clotting tests were normal: PT 12.5s (control 13s), APTT 36s

${ }^{1}$ University Medical Unit, Teaching Hospital Anuradhapura, Departments of ${ }^{2}$ Community Medicine and ${ }^{2}$ Medicine, Faculty of Medicine and Allied Sciences, Rajarata University of Sri Lanka.

Correspondence: VV, e-mail: <vvijitharan@gmail.com>. Received 25 November 2015 and revised version accepted 8 February 2016.

This is an open-access article distributed under the terms of the Creative Commons Attribution License, which permits unrestricted use, distribution, and reproduction in any medium, provided the original author and source are credited. 
(control 35s). AST was 61 $\mu / 1$ (normal range0-35 $\mu / 1$ ), ALT was $23 \mathrm{u} / \mathrm{l}$ (normal range $0-35 \mu / \mathrm{l}$ ) and amylase was $89 \mu / \mathrm{l}$ (normal range $0-100 \mu / 1)$. Serum creatine phosphokinase was $824 \mu / 1$ (normal range less than $400 \mu / \mathrm{l}$ ) after cardiopulmonary resuscitation. The random plasma sugar was normal. He died after receivingartificial ventilation and supportive care for two weeks.

At autopsy, brain was oedematous with diffuse petechial haemorrhages. Both lungs were congested and oedematous. Collapsed segments were noted in middle and lower lobes of the right lung. There was left ventricular hypertrophy and artherosclerotic plaques in the aorta. Upper airway and oesophagus were oedematous. Stomach showed a colourless fluid with an unpleasant odour. Both kidneys showed fatty infiltrations. Liver and spleen were normal. Toxicological analysis could not be performed because the Government Analyst's Department and Medical Research Institute informed of their inability to analyse blood or tissue samples for plant growth regulators. Container of 'Cycocel ${ }^{\circledR}$ ' with the label and residual chemical brought with the patient helped to identify the poison.

\section{Discussion}

Chlormequat chloride is a colourless solution with an unpleasant odour. Clinical features of chlormequat chloride poisoning resemble that of anticholinesterase compounds even though it is not an acetyl-cholinesterase inhibitor [4-6]. It acts by causing stimulation of muscarinic receptors and depolarising blockage of nicotinic receptors in the neuromuscular junction [2,4]. Consequent neuromuscular dysfunction and respiratory paralysis leads to asphyxiation and death [4, 5].

Chlormequat is completely absorbed from the gastrointestinal tract, reaches maximum plasma concentration in two hours, and is mostly excreted via urine in 24 hours [2]. Dose of chlormequat which causes acute toxicity in humans is not known, but fatalities have occurred from ingestion volumes ranging from of a mouthful to $150 \mathrm{ml}$ [6-8]. Acute ingestion of chlormequat produces mucosal irritation, excessive salivation, vomiting, sweating, blurring of vision, miosis, bradycardia, ventricular arrhythmias, cardiac or respiratory arrest, acute pulmonary oedema, coma, seizures and liver degeneration [4-9]. Autopsy findings from previously reported cases have revealed cerebral oedema, pulmonary oedema and congestion of upper airway and oesophagus [7, 8].

Toxinet database recommends single administration of activated charcoal soon after ingestion of poison [4]. Symptomatic treatment with monitoring for hypotension, dysrhythmias, respiratory depression, hypoglycemia, electrolyte disturbance and hypoxia is recommended. Early use of ventilator support with positive end expiratory pressure is also advised. Benzodiazepines are used to control fits. Currently no antidote is available. There is a risk of treating these patients with atropine if misdiagnosed as organophosphate or carbamate poisoning, because acute poisoning mimics anticholinesterase toxicity. Atropine does not act on nicotinic receptors of neuromuscular junctions which are affected by chlormequat too,and results in respiratory paralysis. Atropine affects absorption and excretion of chlormequat and is associated with high mortality $[4,10]$. Even though treatment with atropine was reported in fatal human cases, it is uncertain whether atropine contributed to death. Atropine is contraindicated in the treatment of acute toxicity; however during initial resuscitation of this patient we gave $0.6 \mathrm{mg}$ of atropine [2, 4]. Forced diuresis has been associated with a good outcome in one patient [5]. Normal serum cholinesterase level may help to differentiate it from anticholinesterase poisoning [5,6].

In conclusion, ingestion of chlormequat chloride can be fatal. Even though chlormequat poisoning clinically mimics poisoning with anticholinesterase compounds, atropine is contraindicated. Currently there is no antidote for chlormequat.

\section{Conflicts of interests}

There are no conflicts of interest.

\section{References}

1. World Health Organization. Preventing Suicide: A Global Imperative 2014: 14-27.

2 European Food Safety Authority. Conclusion on the peer review of the pesticide risk assessment of the active substance chlormequat. EFSA Scientific Report 2008; 179: 8-14.http://www.efsa.europa.eu/en/scdocs/doc/179r.pdf (accessed on Aug 09, 2015).

3 United States environmental protection agency office of pesticide programs. Registration eligibility decision for chlormequat chloride, 2007.http://www.archive.epa.gov/ pesticides/rigistration/web/pdf/chlormequat_red.pdf (accessed on Aug 09, 2015).

4 TOXNET - toxicology data network of National Library of Medicine.http://toxnet.nlm.nih.gov/cgi-bin/sis/search/ a?dbs+hsdb:@term+@DOCNO+1541 (accessed on Aug 09, 2015).

5 Yang GH, Kechkeche D, Belhadj-Tahar H, Verdu A, Sadeg N. Case Study: Suicide attempt by intentional ingestion of Chlormequat Forensic. Med Anat Research 2015; 3: 39-42.

6 Nisse P, Majchrzak R, Kahn J Ph, Mielcarek P A, MathieuNolf M. Chlormequat poisoning is not without risk: Examination of seven fatal cases. J Forensic Leg Med 2015; 36: 1-3.

7 Bardale R, Sonar V, Waghmare S. Fatal poisoning with plant growth regulator - chlormequat. J Punjab Acad Forensic Med Toxicol 2012; 12: 102-3.

8 Winek CL, Wahbe WW, Edelstein JM. Sudden death following accidental ingestion of chlormequat. $J$ Anal Toxicol 1990; 14: 257-8.

9 Freisleder A, Bresserer K, Mallach HJ. Suicide with a Supposedly Safe Plant Growth Regulator. Beitr Gericht I Med 1989; 47: 107-10.

10 Romanowski $\mathrm{H}$. Effect of atropine sulfate on resorption and excretion of chlorocholine chloride in rats after a single dose. Ann Univ Mariae Curie Sklodowska Med 1981; 36: 31-41. 